\title{
Efforts to Improve Science Learning Results About Health Disorders in Blood Circular Organs Using IT-Based Media
}

\author{
Lisfaatun \\ SD IT Robbani Kendal \\ lisfaatun123@gmail.com
}

Article History

accepted 14/11/2020

approved 21/11/2020

published $26 / 11 / 2020$

\begin{abstract}
The purpose of this study was to improve student learning outcomes in science muple at SD IT Robbani Kendal class VA by using IT-based media. This Classroom Action Research was carried out in three cycles consisting of: planning, implementing, observing and reflecting. In the first cycle, the students who completed the post test were $62.5 \%$. In the second cycle students who completed after carrying out the post test were $87.5 \%$. In cycle III students who completed after carrying out the post test were $96 \%$. These results indicate that IT-based media can improve student learning outcomes, especially science class VA muple at SD IT Robbani Kendal.
\end{abstract}

Keywords: learning outcomes, it-based media, science

\section{Abstrak}

Tujuan dari penelitian ini adalah untuk meningkatkan hasil belajar siswa pada mupel IPA di SDIT Robbani Kendal kelas VA dengan menggunakan media berbasis IT. Penelitian Tindakan Kelas ini dilaksanakan dengan tiga siklus yang terdiri dari: perencanaan, pelaksanaan, observasi dan refleksi. Pada siklus I peserta didik yang tuntas setelah melaksanakan post test sebesar $62,5 \%$. Pada siklus II peserta didik yang tuntas setelah melaksanakan post test sebesar $87,5 \%$. Pada siklus III peserta didik yang tuntas setelah melaksanakan post test sebesar $96 \%$. Hasil ini menunjukan bahwa media berbasis IT dapat meningkatkan hasil belajar siswa khususnya mupel IPA Kelas VA di SD IT Robbani Kendal.

Kata kunci: hasil belajar, media berbasis IT, IPA

Social, Humanities, and Education Studies (SHEs): Conference Series https://jurnal.uns.ac.id/shes 


\section{PENDAHULUAN}

Rendahnya hasil belajar siswa merupakan salah satu masalah dalam pembelajaran di sekolah. Hasil belajar ini dipengaruhi oleh berbagai faktor, baik faktor internal maupun faktor eksternal. Bloom mengemukakan adanya tiga faktor utama yang mempengaruhi hasil belajar, yaitu kemampuan kognitif, motivasi berprestasi dan kualitas pembelajaran[1].

Model pembelajaran yang digunakan pendidik memang bisa menjadi 'konduktor' yang ampuh untuk menghantarkan materi pembelajaran. Di lapangan sering dijumpai guru yang dapat menguasai materi belajar dengan baik tetapi tidak dapat melaksanakan kegiatan pembelajaran dengan baik. Hal ini bisa jadi karena kegiatan belajar tersebut tidak didasarkan pada model pembelajaran yang sesuai sehingga motivasi belajar yang diperoleh siswa pun rendah.

Untuk meningkatkan motivasi belajar siswa perlu diperhatikan juga sarana dan prasana yang menunjang. Tetapi dalam hal ini belum semua sekolah memiliki sarana dan prasarana yang yang memadai. Seperti yang tertera dalam Permendikbud nomor 68 tahun 2014 bahwa dalam rangka mewujudkan situasi pembelajaran yang mendukung potensi peserta didik perlu didukung dengan pemanfaatan teknologi informasi dan komunikasi yang dapat mengeksplorasi sumber belajar secara efektif dan efesien dengan memaksimalkan peran guru Teknologi Informasi dan Komunikasi dan pengelolaan informasi di sekolah.

Salah satu faktor yang mempengaruhi prestasi siswa adalah motivasi. dengan adanya motivasi, siswa akan belajar lebih keras, ulet, tekun dan memiliki konsentrasi penuh dalam proses belajar. Dorongan Motivasi dalam belajar merupakan salah satu hal yang perlu dibangkitkan dalam upaya pembelajaran di sekolah.

Rendahnya motivasi belajar siswa ditunjukkan dengan sikap siswa yang cenderung ramai dengan teman sebangku atau teman sebelahnya, mengobrol dengan teman, kurang aktif dalam proses pembelajaran, siswa sulit memahami materi yang disampaikan karena guru belum menggunakan media dalam pembelajaran IPA, sebagian siswa enggan bertanya ketika ada penjelasan yang kurang dipahami, dan siswa tidak dapat mengerjakan soal yang diberikan guru dengan benar karena kurang fokus saat mengerjakan.

Motivasi belajar yang rendah tentunya sangat berpengaruh terhadap hasil prestasi belajar. Hasil prestasi belajar siswa kelas VA SD IT Robbani Kendal di bawah KKM. Penggunaan media pembelajaran yang praktis dan efektif tentunya dapat meningkatkan prestasi belajar IPA serta akan mencapai tujuan yang diharapkan. Penggunaan media pembelajaran yang praktis dalam proses belajar mengajar mampu menciptakan suasana belajar yang efektif dan menyenangkan, serta dapat memudahkan siswa dalam menerima dan mengolah informasi yang diterimanya selain itu, dapat memberikan kesan pada diri siswa. Siswa akan berupaya untuk merespon dengan berbagai inderanya sehingga informasi tersebut akan lebih mudah dicerna dan disimpan dalam ingatannya. Untuk mengatasi permasalahan pembelajaran yaitu rendahnya prestasi belajar IPA siswa kelas VA SD IT Robbani Kendal peneliti menetapkan alternatif tindakan dengan menggunakan sebuah media pembelajaran.

Menurut Syaodih (2003:112) media pembelajaran merupakan segala sesuatu yang dapat digunakan untuk menyalurkan pesan atau isi pelajaran, merangsang pikiran, perasaan, perhatian, dan kemampuan siswa, sehingga dapat mendorong proses belajar mengajar. Media pembelajaran yang digunakan dalam penelitian ini adalah media pembelajaran berbasis IT (Information and Technology).

Menurut Kustandi (2010:30) media pembelajaran berbasis IT merupakan cara menghasilkan atau menyampaikan materi dengan menggunakan sumber-sumber yang berbasis mikro-processor. Dalam penelitian ini media pembelajaran berbasis $I T$ yang digunakan adalah power point dan video. Berkaitan dengan hal di atas maka peneliti 
mencoba mengaplikasikan penggunaan media pembelajaran berbasis IT untuk meningkatkan motivasi dan prestasi belajar dalam proses pembelajaran IPA.

Dengan demikian, Penelitian ini bertujuan untuk mendeskripsikan upaya meningkatkan hasil belajar IPA tentang Gangguan Kesehatan Pada Organ Peredaran Darah menggunakan media berbasis IT pada siswa kelas VA SD IT Robbani Kecamatan Kendal Kabupaten Kendal tahun pelajaran 2020/2021. Adapun rumusan masalah pada penelitian ini adalah bagaimana upaya meningkatkan hasil belajar IPA tentang Gangguan Kesehatan Pada Organ Peredaran Darah dengan menggunakan media berbasis IT pada siswa kelas VA SD IT Robbani Kecamatan Kendal Kabupaten Kendal tahun pelajaran 2020/2021?

\section{METODE}

Penelitian ini adalah penelitian tindakan kelas (Classroom Action Research) dengan menggunakan media berbasis IT. Menurut Hopkins (1993), penelitian tindakan kelas diawali dengan perencanaan tindakan (Planning), penerapan tindakan (action), mengobservasi dan mengevaluasi proses dan hasil tindakan (observation and evaluation). Sedangkan prosedur kerja dalam penelitian tindakan kelas terdiri atas empat komponen, yakni perencanaan (planning), pelaksanaan (acting), pengamatan (observing), dan refleksi (reflecting). Analisis penelitian ini adalah analisis deskriptif kuantitafif kualitatif dimana dalam penelitian ini selain penyajian hasil berupa data maupun angka peneliti juga menentukan bagaimana cara pengolahan hasil penelitian yakni dengan membuat analisisnya dengan menggunakan media berbasis IT. Penelitian ini dilaksanakan pada peserta didik kelas VA SD IT Robbani Kendal Tahun Pelajaran 2020/2021 selama tiga siklus secara daring menggunakan aplikasi Zoom meet dengan satu pertemuan di setiap siklusnya. Siklus I dilaksanakan pada tanggal 2 November 2020. Siklus II dilaksanakan pada tanggal 9 November 2020. Siklus III dilaksanakan pada tanggal 20 November 2020. Teknik pengumpulan data yang dilakukan dengan observasi dan tes,

\section{HASIL DAN PEMBAHASAN}

Kondisi awal sebelum diadakan penelitian tindakan kelas siswa kelas VA SD IT Robbani Kendal tema 4 Sehat Itu Penting, Subtema 2 Gangguan Kesehatan Pada Organ Peredaran Darah materi IPA ketuntasan klasikal sebesar $58.33 \%$. Hasil belajar siswa menunjukkan dari 24 siswa hanya 14 siswa saja yang tuntas dengan KKM 75, sedangkan 10 siswa belum tuntas. Menyadari hal tersebut, guru melakukan refleksi dan mengidentifikasi masalah. Akhirnya, untuk memperbaiki hasil pembelajaran yang tidak sesuai dengan harapan tersebut, guru memutuskan untuk melaksanakan penelitian tindakan kelas dengan menggunaan media berbasis IT dalam pembelajaran. Deskripsi tentang data dan hasil tindakan perbaikan pembelajaran yang dilakukan peneliti dalam tiga siklus. Berikut ini adalah hasil belajar peserta didik pada siklus I yang bisa dilihat pada tabel berikut:

\section{Tabel 1. Hasil Belajar Muatan Pelajaran IPA Siklus 1}

\begin{tabular}{ccc}
\hline No. & Pencapaian & Data Siklus 1 \\
\hline 1. & Nilai terendah & 60 \\
2. & Nilai tertinggi & 90 \\
\hline
\end{tabular}


SHEs: Conference Series 3 (3) (2020) 985- 991

\begin{tabular}{|c|c|c|}
\hline & Rata-rata & 78,75 \\
\hline 4. & Ketuntasan klasikal & $62,5 \%$ \\
\hline 5. & Ketidaktuntasan & $37,5 \%$ \\
\hline 6. & Siswa tuntas & 15 \\
\hline 7. & Siswa tidak tuntas & 9 \\
\hline
\end{tabular}

Dari tabel diatas dapat disajikan ke dalam diagram berikut ini:

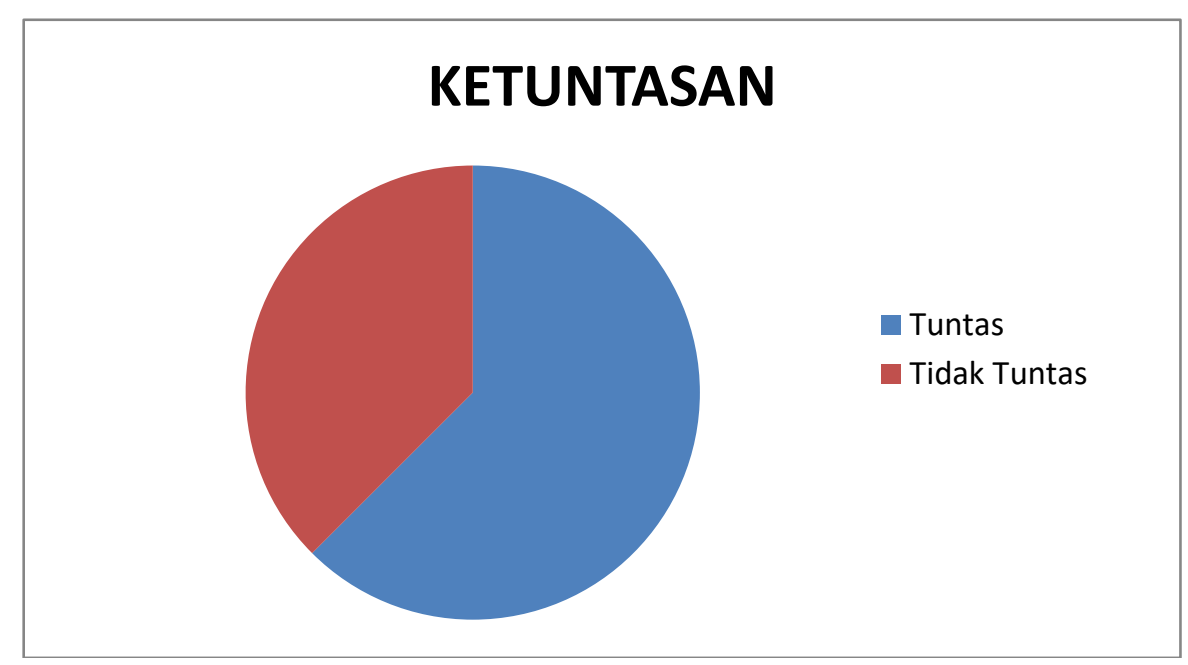

Diagram 1 Hasil Belajar Muatan Pelajaran IPA Siklus 1

Dari tabel 1 dan diagram 3, menunjukkan bahwa nilai rata-rata kelas VA dalam pembelajaran tematik terpadu tema 4 Sehat Itu Penting subtema 2 Gangguan Kesehatan pada Organ Peredaran Darah, pada muatan pelajaran IPA materi Gangguan peredaran darah dan penyebabnya adalah 78,75 dengan nilai terendah 60 dan nilai tertinggi 90 . Sebanyak 15 siswa $(62,5 \%)$ pada siklus 1 sudah mengalami ketuntasan, sedangkan 9 siswa (37,5\%) belum tuntas. Penilaian tersebut berdasarkan KKM yang telah ditetapkan sekolah yaitu $\geq 75$.

Berdasarkan hasil penelitian siklus I diperoleh data hasil belajar kompetensi pengetahuan siswa kelas VA SD IT Robbani Kendal pada muatan pelajaran IPA dalam pembelajaran tema 4 Sehat Itu Penting Subtema 2 Gangguan Kesehatan pada Organ Peredaran Darah dengan menggunakan media berbasis IT perlu dianalisis kembali bersama kolaborator untuk melakukan perbaikan pada siklus II. Berikut ini adalah hasil belajar peserta didik pada siklus II yang bisa dilihat pada tabel berikut: 
Tabel 2 Hasil Belajar Muatan Pelajaran IPA Siklus 2

\begin{tabular}{clc}
\hline No. & Pencapaian & Data Siklus 2 \\
\hline 1. & Nilai terendah & 70 \\
2. & Nilai tertinggi & 100 \\
3. & Rata-rata & 83,75 \\
4. & Ketuntasan klasikal & $87,5 \%$ \\
5. Ketidaktuntasan & $12,5 \%$ \\
6. Siswa tuntas & 21 \\
7. Siswa tidak tuntas & 3 \\
\hline
\end{tabular}

Dari tabel diatas dapat disajikan ke dalam diagram berikut ini:

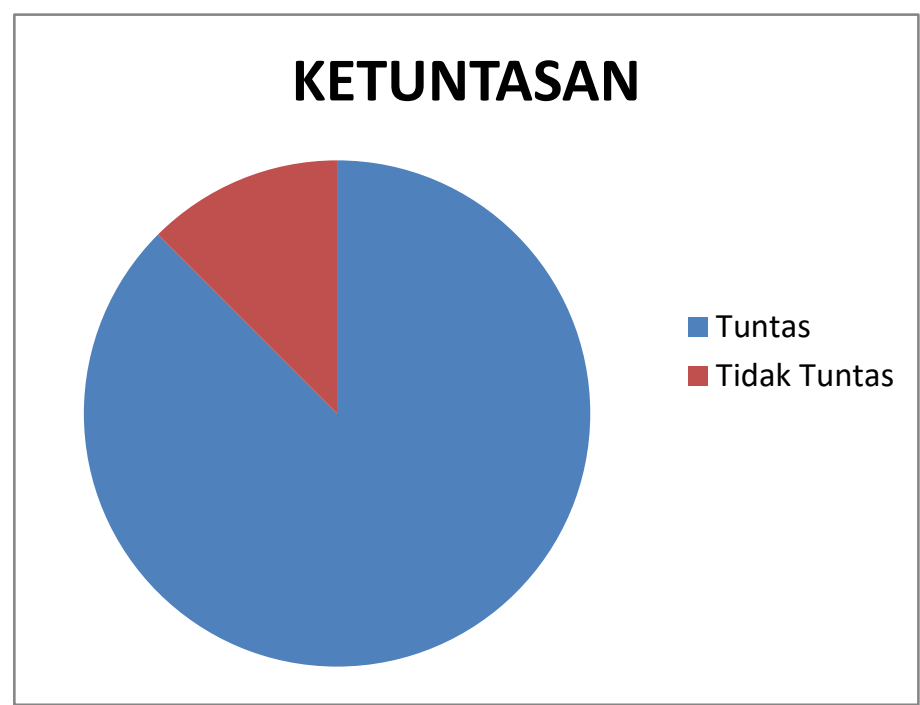

Diagram 2 Hasil Belajar Muatan Pelajaran IPA Siklus 2

Dari tabel 2 dan diagram 2, menunjukkan bahwa nilai rata-rata kelas VA dalam pembelajaran tematik terpadu tema 4 Sehat Itu Penting subtema 2 Gangguan Kesehatan pada Organ Peredaran Darah, pada muatan pelajaran IPA materi Gangguan peredaran darah dan penyebabnya adalah 83,75 dengan nilai terendah 70 dan nilai tertinggi 100 . Sebanyak 21 siswa $(87,5 \%)$ pada siklus 2 sudah mengalami ketuntasan, sedangkan 3 siswa (12,5\%) belum tuntas. Penilaian tersebut berdasarkan KKM yang telah ditetapkan sekolah yaitu $\geq 75$.

Berdasarkan hasil penelitian siklus II diperoleh data hasil belajar kompetensi pengetahuan siswa kelas VA SD IT Robbani Kendal pada muatan pelajaran IPA dalam pembelajaran tema 4 Sehat Itu Penting Subtema 2 Gangguan Kesehatan pada Organ Peredaran Darah dengan menggunakan media berbasis IT sudah berhasil. Indikator keberhasilan hasil belajar dari penelitian ini didasarkan pada peserta didik telah mencapai nilai rata-rata yaitu 75 dan apabila $80 \%$ peserta didik dalam kelas telah mampu menguasai keterampilan mencari tahu suatu informasi. Pada siklus II Sebanyak 21 siswa $(87,5 \%)$ sudah mengalami ketuntasan, sedangkan 3 siswa (12,5\%) belum tuntas. 
Setelah melakukan refleksi pada siklus II, maka diputuskan untuk melanjutkan pada siklus III. Hal ini dilakukan agar mengetahui sejauh mana penggunaan media berbasis IT tidak hanya meningkatkan tetapi juga mempertahankan hasil belajar peserta didik.

Hasil belajar peserta didik siklus III dapat dilihat pada tabel berikut:

Tabel 3 Hasil Belajar Muatan Pelajaran IPA Siklus 3

\begin{tabular}{|c|c|c|}
\hline No. & Pencapaian & Data Siklus 3 \\
\hline & Nilai terendah & 70 \\
\hline 2. & Nilai tertinggi & 100 \\
\hline 3. & Rata-rata & 84,58 \\
\hline 4. & Ketuntasan klasikal & $96 \%$ \\
\hline 5. & Ketidaktuntasan & $4 \%$ \\
\hline & Siswa tuntas & 23 \\
\hline & Siswa tidak tuntas & 1 \\
\hline
\end{tabular}

Dari tabel diatas dapat disajikan ke dalam diagram berikut ini:

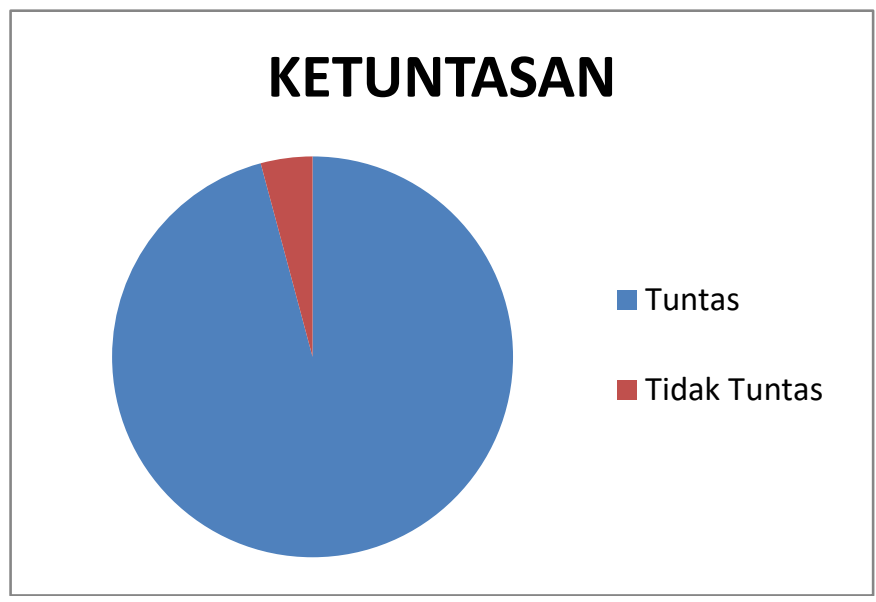

Diagram 3 Hasil Belajar Muatan Pelajaran IPA Siklus 3

Dari tabel 3 dan diagram 3, menunjukkan bahwa nilai rata-rata kelas VA dalam pembelajaran tematik terpadu tema 4 Sehat Itu Penting subtema 2 Gangguan Kesehatan pada Organ Peredaran Darah, pada muatan pelajaran IPA materi Gangguan peredaran darah dan penyebabnya adalah 84,58 dengan nilai terendah 70 dan nilai tertinggi 100. Sebanyak 23 siswa (96\%) pada siklus 3 sudah mengalami ketuntasan, sedangkan 1 siswa (4 \%) belum tuntas. Penilaian tersebut berdasarkan KKM yang telah ditetapkan sekolah yaitu $\geq 75$. 
Dari tiga siklus yang sudah dilaksanakan dapat dipastikan bahwa media berbasis IT dapat meningkatkan hasil belajar peserta didik pada mupel IPA Kelas VA di SD IT Robbani Kendal.

\section{SIMPULAN}

Berdasarkan hasil perbaikan pembelajaran tema 4 Sehat Itu Penting sub tema 2 Gangguan Kesehatan Pada Organ Peredaran Darah melalui penggunaan media berbasis IT dapat diambil kesimpulan sebagai berikut: (1). Penggunaan media berbasis IT dapat meningkatkan hasil belajar siswa kelas VA SD IT Robbani Kendal dalam pembelajaran tema 4 Sehat Itu Penting sub tema 2 Gangguan Kesehatan Pada Organ Peredaran Darah. Hal ini dapat dibuktikan dengan meningkatnya ketuntasan belajar siswa dari kondisi awal sebelum tindakan dari 24 siswa hanya 14 siswa $(58,33 \%)$ yang tuntas dengan KKM 75, pada perbaikan pembelajaran siklus I ketuntasan belajar siswa meningkat menjadi 15 siswa (62,5\%). Kemudian setelah diadakan perbaikan pembelajaran siklus II. ketuntasan belajar siswa kembali meningkat menjadi 21 siswa (87,5\%). (2). Penggunaan media berbasis IT dapat meningkatkan hasil belajar siswa kelas VA SD IT Robbani Kecamatan Kendal Kabupaten Kendal dalam materi IPA tema 4 Sehat Itu Penting sub tema 2 Gangguan Kesehatan Pada Organ Peredaran Darah. Hal ini dapat dibuktikan dengan hasil observasi beberapa siswa kelas VA SD IT Robbani Kendal.

\section{DAFTAR PUSTAKA}

Arief S. Sadiman (2010). Media Pendidikan Pengertian, Pengembangan, dan Pemanfaatnnya. Jakarta: Rajawali Pres.

Azhar Arsyad. (2009). Media Pembelajaran. Jakarta: Rajawali Pers. Basuki Wibawa. (1991). Media Pengajaran. Jakarta: Depdikbud.

Daryanto. (2011). Penelitian Tindakan Kelas dan Penelitian Tindakan Sekolah Beserta Contoh-Contohnya. Yogyakarta: Gava Media.

Depdiknas. (2005). Kamus Besar Bahasa Indonesia. Jakarta: Balai Pustaka.

I GAK Wardani. (2006). Penelitian Tindakan Kelas. Jakarta: Universitas Terbuka.

Kementerian Pendidikan dan Kebudayaan. 2017. Tematik Terpadu Kurikulum2013. Untuk SD/MI Kelas V. Jakarta:Kemendikbud.

Mangkunegara.(2000).Manajemen Sumber Daya Manusia Perusahaan. Bandung:PT. Remaja Rosdakarya.

Mulyono Abdurrahman. (2010). Pendidikan Bagi Anak Berkesulitan Belajar. Jakarta:PT. Rineka Cipta.

Ngalim Purwanto. (2010). Prinsip-prinsip dan Teknik Evaluasi Pengajaran.Bandung: Remaja Rosdakarya.

Nurhasanah. (2007). Kamus Besar Bergambar Bahasa Indonesia. Jakarta: Bina Sarana Pustaka.

Sumber:http://annisa-siregar.blogspot.com/2011/12/model-pembelajaran-berbasisit_07.html 